\title{
Common Sports-related Musculoskeletal Injuries presenting to the Emergency Department
}

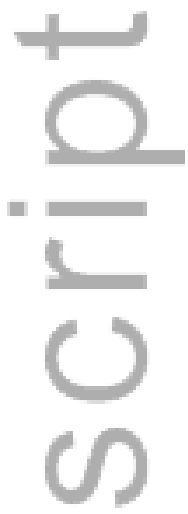

Browne Gary J \& Barnett Peter LJ

Children's Hospital Institute of Sports Medicine, The Children's Hospital at Westmead, Sydney Children's Hospitals Network and Royal Children's Hospital, MCRI and

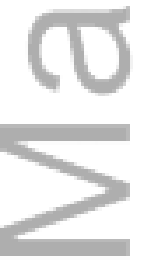
Department of Paediatrics, Melbourne

Correspondence to

Prof Gary J Browne

Children's Hospital Institute of Sports Medicine

The Children's Hospital at Westmead

Locked Bag 4001

Westmead, NSW

2145

gary.browne@health.nsw.gov.au

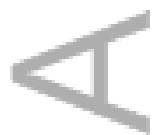

This is the author manuscript accepted for publication and has undergone full peer review but has not been through the copyediting, typesetting, pagination and proofreading process, which may lead to differences between this version and the Version of Record. Please cite this article as doi: 10.1111/jpc.13101

This article is protected by copyright. All rights reserved. 


\section{ABSTRACT}

Young athletes are specialising in sports at a younger age, placing the developing musculoskeletal system under considerable stress. Overuse injuries such as apophysitis are chronic in nature and account for a large proportion of musculoskeletal injuries suffered by young athletes, however with an increased emphasis on success in sport, tendinopathy and fatigue fractures are now being reported with increasing frequency, in the adolescent population. Correct diagnosis and early protection, rest, ice, compression, and elevation (PRICE) therapy is critical, along with supervised rehabilitation an expert in paediatric and adolescent sports medicine. Acute traumatic knee injury and ankle sprain account for most acute injuries. Although most are soft-tissue in nature, radiography may be useful in specific situations before early initiation of PRICE therapy. These injuries will also require follow-up by an expert in paediatric and adolescent sports medicine to confirm the diagnosis and instigate ongoing rehabilitation and/or orthopaedic referral. Many of these injuries are preventable and due consideration should be given to simple prevention strategies.

Key words: athlete, musculoskeletal, overuse, soft-tissue, sprain

\section{Key Points}

1. Many sports injuries in children are the result of early specialisation and excessive training load.

2. Overuse injuries are best treated initially with PRICE therapy and referral to sports medicine for further evaluation and rehabilitation. 
3. If an acute sports injuries is determined to be soft-tissue in nature, due consideration should be given to imaging i.e. plain $\mathrm{x}$-ray to exclude occult fracture, with referral to sports medicine for follow-up.

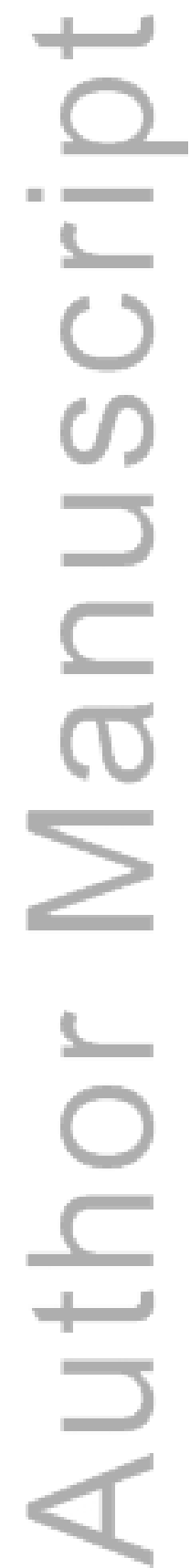

This article is protected by copyright. All rights reserved. 


\section{INTRODUCTION}

Throughout Australia, children participate in team sports and likely many more are involved in individual sports. Although little data exists documenting the extent of participation within this population, it is clear that large numbers of children do not limit their sports to a given season and are involved throughout the calendar year. ${ }^{1}$ Further, with an increased emphasis on competitive success that seemingly has become widespread at younger ages in youth sports, pressure exists for youth to begin training with greater frequency and intensity at younger ages than in the past. This, sometimes coupled with parental hopes of securing state and national team selections, and even professional careers, has led to participation far beyond traditional school-based and community-supported programs. This emphasis on year-round training, competition, single-sport specialisation and competitive success sets the stage for injury. Many children and adolescents with a sports injury initially present to the emergency department for assessment. It is therefore important for emergency physicians to understand how these injuries may occur, what initial treatment is appropriate and who should be referred for specialist evaluation. This article will focus on the three most common musculoskeletal sports injuries that present to the emergency department: overuse injuries, acute traumatic knee injuries and ankle sprains.

\section{EPIDEMIOLOGY}

In Australia, surveillance programs for high school sports found football to be the riskiest sport as well as netball, basketball, and soccer - this is likely related to the type of sport as 
well as the number of participants per sport. ${ }^{1,2}$ Girls accounted for $45 \%$ of all injuries among children. ${ }^{3}$ Approximately half of the injuries were acute, and half were chronic. Sixty-two percent of acute injuries were soft tissue injuries (muscle, tendon, or ligament sprains, strains, or contusions). Most of the chronic injuries (53\%) involved epiphyseal and apophyseal growth plates and articular cartilage. The occurrence of growth plate injuries is unique to the paediatric population. ${ }^{4}$

\section{MUSCULOSKELETAL DEVELOPMENT}

Children's musculoskeletal system has significant differences over adults e.g. high water/lower mineral content, less brittle bones, thicker periosteum and richer blood supply in pediatric bone. The physis (growth plate) is a cartilaginous structure that is weaker than bone, predisposed to injury (particularly during rapid growth phases). Ligaments in children are functionally stronger than bone therefore children are more likely to sustain fractures rather than sprains. Active bone growth precedes muscle and tendon lengthening, requiring each muscle tendon unit to lengthen or stretch out to keep up with the bone growth. Limited muscle and tendon flexibility predisposes to increased overuse injuries in puberty. ${ }^{5}$

\section{OVERUSE INJURIES}

Anatomic structures that are subjected to repetitive loading during sport participation incur micro trauma. With sufficient recovery between exposures, the tissue (e.g., bone or tendon) can remodel and adapt to the imposed stresses. Overuse injuries develop when repeated mechanical loading exceeds the remodelling capability of the structure under 
stress. Injury can occur with moderate intensity loading over extended periods when recovery time is not sufficient. Alternatively, injury may develop with repeated highintensity, short-duration loading even when recovery is planned and provided. ${ }^{5,6,7}$

\section{Apophysitis}

Apophyseal injuries occur at immature tendon-bone attachment sites (see table 1). The weakness of the growth cartilage relative to the tendon together with decreased flexibility, is thought to create increased traction at the apophyseal insertion of the tendon, and has been proposed as a factor in apophyseal injury development. ${ }^{8,9}$

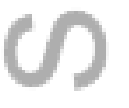

Diagnosis of apophysitis is based on physical examination and history. The typical clinical presentation is the active child who complains of pain at the affected site that is worsened with activity or painful after stopping activity. Examination will specifically reveal tenderness at the location of apophyseal injury, figure 1. Range of motion is often normal, but pain can be elicited with stretching or strength testing of the muscle tendon unit. Patients with the suspicion of appophysitis do not need radiography because the diagnosis is a clinical one. However if radiographs obtained widening of the apophysis may be evident as well as apophyseal hypertrophy or ossicle formation. A general approach to treatment can be seen in table 2. ${ }^{10}$

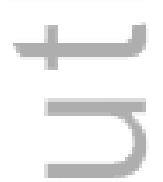

Acute avulsion at the site of the apophysis presents with sudden onset of pain during sporting activity. ${ }^{12}$ Patients are generally very tender over this site and unable to hold 
distal structure against gravity (e.g. lower leg in tibial tuberosity avulsion) X-ray in these cases is essential to confirm an avulsion. Surgical repair is required in some cases (e.g. tibial tuberosity) but not in others (ASIS / AlIS / Iliac crest / Ischial tuberosity).

\section{Tendinopathies in the Young Athlete ${ }^{17,18}$}

In athletes of all ages (mainly teens through to 30yr olds), vigorous and repetitive physical activity that leads to excessive loading of tendons is considered as the primary pathological cause of degeneration. The response to continuous tendon overload in the young is specifically inflammation of the tendon, which is reversible. If the adolescent continues unabated with the offending activity over time this may be followed by degeneration which is more chronic and difficult to treat. Inflammation and degeneration can occur separately or in concert. If cumulative microtrauma persists without adequate rest from activity, then worsening degeneration or tendon rupture may occur (rarely).

With an increased emphasis on success in sport in the young athlete, tendinopathy is now more commonly seen, e.g. in overhead activity such as throwing or racquet sports (i.e. cricket and tennis) and running or jumping activity (i.e. basketball or dancing). The common sites are summarized in table $3^{19,20}$

Making the diagnosis of a tendinopathy relies on history and physical examination. The child will present with prolonged pain in the affected area, likely related to overuse and worsened with activity. X-rays are often normal; however MRI and/or ultrasound can be useful in making the diagnosis in difficult cases. The principles of management are 
outlined in table 4. Refractory cases may benefit from referral to an expert in paediatric and adolescent sports medicine (e.g. paediatrician with an interest in sports medicine, sports physician or physiotherapist) who will provide a structured rehabilitation program. ${ }^{21}$

\section{Stress or fatigue fractures in the young athlete}

Stress fractures are overuse injuries as distinct from acute fractures in which bone injury occurs after a single traumatic event. This is a weakening of bone that occurs from repetitive compressive or tensile stresses on the bone. ${ }^{23}$

Making the diagnosis of a stress fracture relies on history and physical examination. The patient usually presents with focal pain in the affected area that is worse with activity or even walking. The hallmark on physical examination is point tenderness on the bone. Xrays are useful if a fracture or callus is visible, but may be normal in the first 3-4 weeks. Bone scan or MRI is commonly used to diagnose stress fractures. These investigations are mandatory in high-risk fractures. Stress fractures in the young athlete should be referred to an expert in paediatric and adolescent sports medicine for a structured rehabilitation program. ${ }^{24}$

The nature of treatment for stress fractures in the young athlete is usually conservative. In the emergency department this consists of non-weight bearing and immobilisation of the affected site in either a plaster or walking boot with follow-up review in 2 weeks. Certain stress fractures do not have the capacity to heal with conservative measures (see table 5). ${ }^{24}$ These high-risk stress fractures should be referred early an expert in paediatric and

This article is protected by copyright. All rights reserved. 
adolescent sports medicine or orthopaedics for potential surgical consideration. The ongoing management for all of the other stress fractures is composed of crutches, walking boot, modification of training regimens, and analgesia.

\section{Patellofemoral pain syndrome (PFPS)}

This is a very common condition in the young athlete. As with other overuse injuries patellofemoral pain is multifactorial in origin. In atheltes of all ages, vigorous and repetitive physical activities leads to excessive loading of the patellofemoral joint as the primary pathology leading to patella pain. ${ }^{25}$

The diagnosis of patellofemoral pain syndrome relies on history and examination. The patient usually presents with diffuse anterior knee pain that is worse with activity or walking. The hallmark of examination is point tenderness on the patellar facets (ie move patella sideways and feel under the medial and lateral sides of the patella). Pain may also be elicitied by compressing the patella against the femur with the leg in extension (patellar grind test). The nature of treatment for patellofemoral pain syndrome is usually conservative following the relative rest and PRICE (Protect from further injury, Rest, Ice, Compresion and Elevation) principles. More refractory cases should be referred to an expert in paediatric and adolescent sports medicine for a structured rehabilitation program. 26

\section{ACUTE TRAUMATIC KNEE INJURY}

This article is protected by copyright. All rights reserved. 
This is a very common presentation to the emergency department often following an acute event on the sports field. In most cases this will result in a traumatic haemarthrosis with rapid onset of swelling, pain and limited range of motion. The following should be considered; complete or partial tear of the anterior cruciate ligament ( $A C L)$, meniscal injury (medial or lateral- usually delayed in onset) and in many cases an acute patella dislocation which has self reduced. The physician should also consider the possibility of a fracture (eg tibial spine or tibial tuberosity avulsion). Isolated lateral collateral ligament (LCL) and Posterior Cruciate Ligament $(\mathrm{PCL})$ injuries are rare in children and will not be discussed. 27,28

The mechanism of injury is important as it usually gives the clinician a good idea of what structures have been injured, see table 6. Patients can report instability (giving way or collapse) and this is commonly related to $A C L$ rupture or patellar instability. A report of locking is usually associated with limitations in knee extension and may have an intraarticular loose body, torn mensicus, avulsed ligament fragments, or bony fragment. An audible pop is usually heard with serious ligament injury in particular ACL tear or a fracture. A ripping sensation may represent a mensical injury or a patella dislocation. A cracking sound can be caused by bone injury or patellar dislocation. Swelling that occurs quickly (within a few hours) may be the result of an ACL tear, intra-articular fracture or patella dislocation. ${ }^{29,30}$ If the mechanism is unclear then other causes of knee pain should be considered, table 7 .

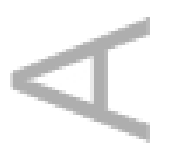


On examination, the presence or absence of an effusion is important. If possible deciding if there is focal tenderness is also helpful. Medial tenderness of the patella is seen in patella dislocation, medial or lateral joint line tenderness is seen in meniscal or ligamentous injury. Stressing of the medial or lateral ligament may also produce pain. A positive lachmans test (with the knee in approximately $30^{\circ}$ of flexion there is a clear increase in laxity compared with the uninjured knee when the tibia is pulled forward or the end point for the ACL on the injuried knee is not distinct / soft) occurs in ACL tear or tibial spine fracture. However in the acute setting this test may be hard to achieve due to the swelling and degree of pain. ${ }^{27,28}$

X-ray is important to rule out a fracture, particularly in the skeletally immature patient as a fracture is more common than ligament injury. ${ }^{32}$ A Segond fracture (an avulsion fracture of the knee which involves the lateral aspect of the tibial plateau) has a high association with disruption of the ACL, figure 2. In suspected patella dislocation a skyline view should also be included to exclude a significant avulsion fracture of the patella or lateral condyle. An $M R I$ is generally required to make the diagnosis of an ACL or meniscal tear. Urgency of this investigation is not time critical.

Once a diagnosis of one of the big four soft tissue injuries is made the approach to the treatment of acute traumatic knee injury (with some minor variation) is much the same. Initial treatment includes, PRICE, with protection in a knee splint and non-weight bearing using crutches. In the acute setting, selective arthrocentesis to drain a tense effusion can relieve distension pain, and allowing for easier examination. The patient should then be 
referred to an expert in paediatric and adolescent sports medicine for repeat examination in 2 weeks to confirm the diagnosis and implement definitive treatment. In patients with chronically painful knee with insidious onset of pain keep in mind potential for tumour near the knee, inflammatory arthritis, hip pathology such as SCFE or an infection.

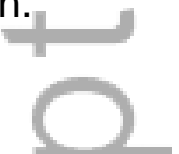

\section{ANKLE SPRAIN}

Ankle sprains are the most frequently seen musculoskeletal injury encountered in emergency departments. Ankle sprains account for up to $40 \%$ of all athletic injuries, especially in basketball, soccer, cross-country running, dance, and ballet. Older children with closed growth plates get ankle sprains more frequently than their younger counterparts. ${ }^{33}$

\section{(1)}

The three main mechanisms of injury of the ankle are inversion, eversion, and dorsiflexion. The most common is inversion injury (95\%), which is responsible for lateral ankle sprains. Medial ankle sprain, which affects the deltoid ligament, is usually caused by plantar flexion with eversion. The last major type of ankle sprain is the infamous syndesmosis, or "high" ankle sprain. This injury occurs with rapid dorsiflexion, eversion and external rotation and is often seen when a child jumps from a considerable height or from sliding (e.g. baseball). This is the most serious type of ankle sprain because it leaves the ankle mortis unstable. 34,35 
In general, the more extensive the ligament injury, the more difficult it is to bear weight, the more swelling noted acutely, and the more ecchymosis that develops over a few days, see table 8. Most of the pain is usually localized over the area of the ATFL, the most commonly injured ligament in lateral ankle sprain. Effusion above the ankle capsule may signify a syndesmotic or high ankle sprain.

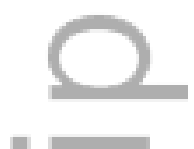

The Low Risk Ankle Rule (LRAR) states that if a child with an ankle injury has a low-risk examination (i.e., tenderness and swelling isolated to the distal fibula and/or adjacent lateral ligaments distal to the tibial anterior joint line), radiographs are not required. ${ }^{36}$ These patients should be treated as for a sprain even though they may have a small distal fibula fracture.

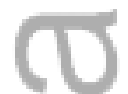

Therapy for ankle sprain in the acute setting should focus on the PRICE principles - this being an established treatment protocol. The patient with a significant ankle sprain (Grade 2-3) should be referred to a sports medicine service for functional rehabilitation. A brief period of immobilisation with a below knee cast leads to speedier recovery in patients with severe ankle sprain and this should be considered in the emergency department before referring an expert in paediatric and adolescent sports medicine . ${ }^{37}$

\section{THE EMERGENCY PHSICIAN AND INJURY PREVENTION}

The emergency physician is an important interface between parents and the sports medicine specialist in terms of prevention. Talking to parents at the time of injury about 
simple prevention strategies can have a profound impact on reducing further injury. By encouraging children not to "play through" pain or injury, emphasising the importance of sport diversification at younger ages and encouraging children to experiment with different activities to develop skills and interest and to prevent burnout and injury. Finally the emergency physician should encourage parents to ensure the young athlete has plenty of rest and recovery following activity (1-2 days free of sport per week) and being cautious about having their children competing on more than one team at the same time.

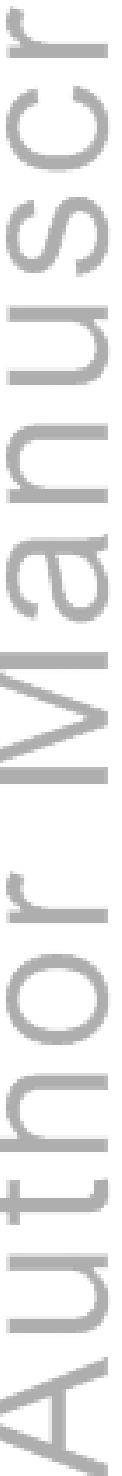

This article is protected by copyright. All rights reserved. 


\section{REFERENCES}

1. National Council of Youth Sports. Report on trends and participation in organized youth sports. NCYS Membership Survey 2008

2. Franklin CC, Weiss JM. Stopping sports injuries in kids: an overview of the last year in publications. Current Opinion in Pediatrics. 2012;24(1):64-7.

3. Stracciolini A, Casciano R, Levey FH. et al Pedaitric sports injuries: a comparison of males versus females. American Journal of Sports Medicine. 2014;42(4):965-72.

4. Stracciolini A, Casciano R, Levey FH. et al Pediatric sports injuries: an age comparison of children versus adolescents. American Journal of Sports Medicine. 2013;41(8):1922-9.

5. DiFiori JP. Evaluation of overuse injuries in children and adolescents. Current Sports Medicine Reports 2010;372-378

6. Cuff S, Loud K, O'Riordan MA. Overuse injuries in high school athletes. Clinical Pediatrics. 2010;49(8):731-6.

7. Soprano JV. Musculoskeletal injuries in the pediatric and adolescent athlete. Current Sports Medicine Reports 2005; 329-334

8. Burns W, Maffulli N. Lower limb injuries in children in sports. Clin Sports Med. 2000; 19(4):637-662.

9. Gholve PA, Scher DM. Khakharia S. Widmann RF. Green DW. Osgood Schlatter syndrome. Current Opinion in Pediatrics. 2007;19(1):44-50.

10. Gillespie H. Osteochondroses and apophyseal injuries of the foot in the young athlete. 2010;265-268 
11. Pontell D. Hallivis R. Dollard MD. Sports injuries in the pediatric and adolescent foot and ankle: common overuse and acute presentations. Clinics in Podiatric Medicine \& Surgery. 2006;23(1):209-31.

12. Koehler SM, Rosario-Quinones F, Mayer J, et al. Understanding acute apophyseal spinous process avulsion injuries. Orthopedics. 2014;37(3):e317-21.

13. MetzI JD. Managing sports injuries in the pediatric office. Pediatrics in Review. 2008;29(3):75-84.

14. Soprano JV, Fuchs SM. Common Overuse Injuries in the Pediatric and Adolescent Athlete. Clinical Pediatric Emergency Medicine 2007;8:7-14.

15. Perhamre S. Lundin F. Norlin R. Klassbo M. Sever's injury; treat it with a heel cup: a randomized, crossover study with two insole alternatives. Scandinavian Journal of Medicine \& Science in Sports. 21(6):e42-7, 2011 Dec.

16. Perhamre S, Janson S, Norlin R, Klassbo M. Sever's injury: treatment with insoles provides effective pain relief. Scandinavian Journal of Medicine \& Science in Sports. $2011 ; 21(6): 819-23$.

17. Selvanetti A, Cipolla M, Puddu G . Overuse tendon injuries: basic science and classification. Oper Tech Sports Med. 1997; 5(3):110-117.

18. Scott A, Ashe MC. Common tendinopathies in the upper and lower extremities 2006;233-241

19. Maffulli N, Wong J, Almekinders LC. Types and epidemiology of tendinopathy. Clin Sports Med. 2003;22(4):675-692.

20. Weiss JM, Arkader A, Wells LM, et al. Rotator cuff injuries in adolescent athletes. Journal of Pediatric Orthopaedics, Part B. 2013;22(2):133-7. 
21. Gaida E, Cook J. Treatment options for patellar tendinopathy: Critical review . 2011 $255-270$.

22. Murtaugh BM, Ihm J. Eccentric training for the treatment of tendinopathy. 2013;175182

23. Snyder RA, Koester MC, Dunn WR. Epidemiology of stress fractures. Clin Sports Med. 2006; 25(1):37-52.

24. Coady CM, Micheli LJ . Stress fractures in the pediatric athlete. Clin Sports Med. $1997 ; 16(2): 225-238$.

25. Grelsamer RP, Klein JR . The biomechanics of the patellofemoral joint. J Orthop Sports Phys Ther. 1998; 28(5):286-298.

26. Patil S, White L, Jones A, et al. Idiopathic anterior knee pain in the young. A prospective controlled trial. Acta Orthop Belg. 2010; 76(3):356-359

27. Davids JR. Pediatric knee: clinical assessment and common disorders. Pediatr Clin North Am. 1996;43:1067-1090.

28. Galanty HL, Matthews C, Hergenroeder AC. Anterior knee pain in adolescents. Clin J Sports Med. 1994;4:176-181.

29. Kocher M, Micheli LJ, Zurakowski D et al. Partial tears of the anterior cruciate ligament in children and adolescents. American Journal of Sports Medicine, 202;697-703.

30. Stanitski C, Harvell JC, Fu F , . Observations on acute knee hemarthrosis in children and adolescents. J Pediatr Orthop. 1993; 13(4):506-510.

31. Eiskjaer S, Larsen ST, Schmidt MB. The significance of hemarthrosis of the knee in children. Arch Orthop Trauma Surg. 1988; 107(2):96-98. 
32. Bullock B, Neto G, Plint A, Validation of the Ottawa knee rule in children: a multicenter study. Ann Emerg Med. 2003; 42(1):48--55.

33. Doherty C. Delahunt E. Caulfield B. Hertel J. Ryan J. Bleakley C. The incidence and prevalence of ankle sprain injury: a systematic review and meta-analysis of prospective epidemiological studies. Sports Medicine. 44(1):123-40, 2014 Jan.

34. Ivins D. Acute ankle sprain: an update. American Family Physician. 2006;74(10):1714-20.

35. Anderson SJ. Evaluation and treatment of ankle sprains. Compr Ther. 1996;22:3038.

36. Boutis K, Grootendorst P, Willan A, et al: Effect of the Low Risk Ankle Rule on the frequency of radiography in children with ankle injuries: CMAJ. 2013;185(15): E731-E738

37. Lamb SE, March JL, Huttoin Jl et al. Collaborative ankle Support trial (CAST Group). Mechanical supports for acute severe ankle sprain: a pragmatic, multicentre, randomised controlled trial. Lancet, 2009,373:575-81

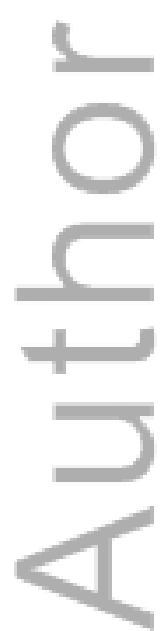


Figure $1 \mathrm{~A}$ - Pain is well localized in apophysitis as seen here in a child with OsgoodSchlatter's disease, B- Anatomic site of the apophysis is the tibial tubercle in a case of Osgood-Schlatter's disease

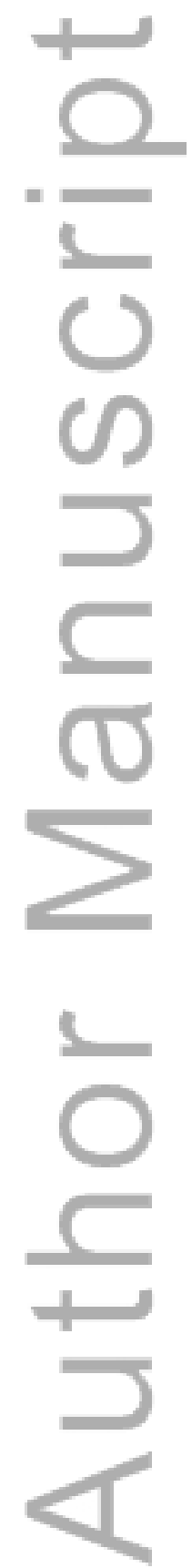

This article is protected by copyright. All rights reserved. 
Figure 2 Segond fracture

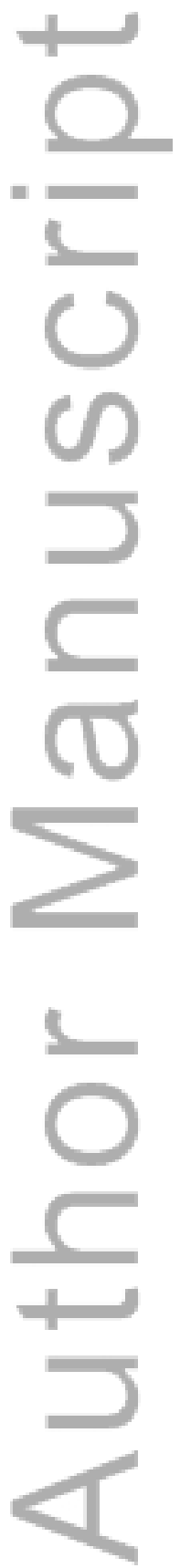

This article is protected by copyright. All rights reserved. 
Table 1 Common Apophyseal Injury sites in Young Athletes

\begin{tabular}{|c|c|c|}
\hline Location & Site of Apophyseal Injury & Muscle / Tendon Involved \\
\hline Knee & $\begin{array}{l}\text { Tibial tubercle (Osgood-Schlatter's } \\
\text { disease }^{9} \text { ); lower pole of Patella } \\
\text { (Sinding-Larsen-Johansson disease) }\end{array}$ & Quadriceps \\
\hline Foot & $\begin{array}{l}\text { Calcaneus }^{10} \text { (Sever's disease); fifth } \\
\text { metatarsal }^{11} \text { (Iselin's disease) }\end{array}$ & $\begin{array}{l}\text { Achilles } \\
\text { Peroneus Brevis }\end{array}$ \\
\hline Elbow $=$ & $\begin{array}{l}\text { Medial epicondyle (Little League } \\
\text { elbow) }\end{array}$ & Ulnar collateral ligament \\
\hline Pelvis & $\begin{array}{l}\text { Ischial tuberosity; } \\
\text { Anterior superior or inferior iliac spine } \\
\text { (ASIS, AIIS); } \\
\text { Iliac crest }\end{array}$ & $\begin{array}{l}\text { Hamstring } \\
\text { Rectoris Femoris / Sartorius } \\
\text { Rectus Abdominus }\end{array}$ \\
\hline
\end{tabular}

ASIS, Anteriosuperior Iliac Spine; AIIS, Anteroinferior Iliac Spine

This article is protected by copyright. All rights reserved. 
Table 2- Treatment of Apophysitis in the Young Athlete ${ }^{13,14}$

\begin{tabular}{|l|l|}
\hline \multicolumn{1}{|c|}{ Diagnosis } & \multicolumn{1}{c|}{ Treatment Option } \\
\hline INITIAL TREATMENT & $\begin{array}{l}\text { Relative rest (no pain with movement), Icing the } \\
\text { affected site and analgesia, Graduated return to } \\
\text { sport with minimal pain. }\end{array}$ \\
\hline SPECIFIC TREATMENT & \\
\hline $\begin{array}{l}\text { Osgood-Schlatter's disease; Sinding- } \\
\text { Larsen-Johanson disease }\end{array}$ & Patella tendon knee strap or knee pad, SSEP \\
\hline Sever's disease & Heel cups, SSEP ${ }^{15,16}$ \\
\hline Iselin's disease & Lace-up ankle brace or lateral heel wedge, SSEP \\
\hline
\end{tabular}

SSEP, Stretching and strengthening exercise program

This article is protected by copyright. All rights reserved. 
Table 3- Tendinopathies in the Young Athlete

\begin{tabular}{|l|l|}
\hline \multicolumn{1}{|c|}{ Location } & \multicolumn{1}{c|}{ Site of Tendon injury } \\
\hline Shoulder & Rotator cuff \\
\hline Hip/pelvis & Hip flexors; iliotibial band \\
\hline Knee & Patella tendon; quadriceps tendon \\
\hline Ankle & Achilles' tendon; posterior tibialis tendon; peroneal tendon \\
\hline
\end{tabular}

()

$\int$

ד

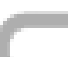

ד

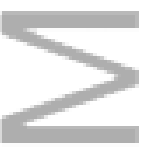

4

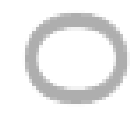

$\frac{5}{5}$

This article is protected by copyright. All rights reserved. 
Table 4- Treatment for Specific Tendinopathies in the Young Athlete

\begin{tabular}{|l|l|}
\hline \multicolumn{1}{|c|}{ Diagnosis } & \multicolumn{1}{c|}{ Treatment Option } \\
\hline INITIAL TREATMENT & $\begin{array}{l}\text { Relative rest, icing the affected site and } \\
\text { analgesia for all tendinopathies, ESSEP }\end{array}$ \\
\hline SPECIFIC TREATMENT & \\
\hline Achilles' tendonitis & Achilles strap, \\
\hline Posterior tibialis tendonitis & Arch supports \\
\hline Peroneal tendonitis & Lateral heel wedge \\
\hline Patellar tendonitis & Patella tendon knee strap \\
\hline Lateral epicondylitis & Counterforce strap \\
\hline
\end{tabular}

ESSEP, Eccentric stretching and strengthening exercise program

This article is protected by copyright. All rights reserved. 
Table 5- Common Stress Fractures in the Young Athlete

\begin{tabular}{|l|l|l|}
\hline \multicolumn{1}{|c|}{ Location } & \multicolumn{1}{c|}{ Site of Fracture } & \multicolumn{1}{c|}{ High Risk Types } \\
\hline Hip/pelvis & Femoral neck, pubic ramus & Anterior femoral neck \\
\hline Thigh & Femoral shaft & \\
\hline Shin & Tibia, fibula & Anterior Tibia \\
\hline Ankle & Medial / Lateral Malleolus / Talus & Medial Malleolus \\
\hline Foot & $\begin{array}{l}\text { Navicular, metatarsals, calcaneus, } \\
\text { cuboid }\end{array}$ & Navicular / Base 5 ${ }^{\text {th }}$ MTP \\
\hline Elbow = & Capitellum, radial head & Capitellum \\
\hline
\end{tabular}

MTP, Metatarsus proximal

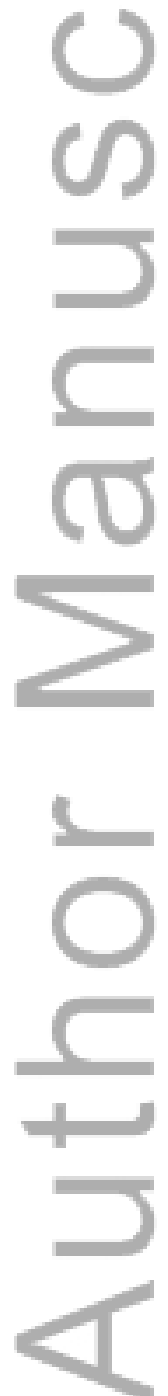

This article is protected by copyright. All rights reserved. 
Table 6- Mechanism of Injuries and associated injuries

\begin{tabular}{|l|l|}
\hline \multicolumn{1}{|c|}{ Mechanism } & \multicolumn{1}{c|}{ Suspected Injury } \\
\hline Blow to outside of knee (valgus stress) & MCL sprain \\
\hline Blow to inside of knee (varus stress) & LCL sprain \\
\hline Hyperextension of knee & ACL sprain \\
\hline Twisting of knee after sudden stop & ACL sprain +/- meniscus tear \\
\hline Knee went "out of joint" & Patellar dislocation/subluxation \\
\hline Pivoting after jumping or twisting & Patellar dislocation/subluxation or mensical tear \\
\hline Fall / struck on tibia with knee flexed & PCL \\
\hline
\end{tabular}

MCL, Medial Collateral Ligament; LCL, Lateral Collateral Ligament; ACL, Anterioal

Cruciate Ligament; PCL, Posterior Cruciate Ligament

This article is protected by copyright. All rights reserved. 
Table 7- Common causes of Knee pain

\begin{tabular}{|l|l|l|}
\hline \multicolumn{1}{|c|}{ Acute injury } & \multicolumn{1}{|c|}{ Semi-acute condition } & \multicolumn{1}{c|}{ Chronic condition } \\
\hline Fracture (femur/tibia/patella) & Osteochondritis dissecans & Inflammatory arthritis \\
Dislocation patella & SCFE & Apophysitis \\
Mensical tear (torn discoid & Loose Body & Anterior Knee pain (PFPS / \\
mensicus) & Tumour (bone / blood) & impingement Hoffa's fat \\
Anterior cruciate ligamanet & Infection (osteomyelitis / & Pad) \\
tear = & Septic Arthrits) & Tendonitis (Quadriceps / \\
Medial collateral ligament & & Patella tendons) \\
tear & & \\
Soft tissue contusion & & \\
Bone bruising & & \\
\hline
\end{tabular}

Slipped capital femoral epiphysis (SCFE), Patellofemoral Pain Syndrome (PFPS)

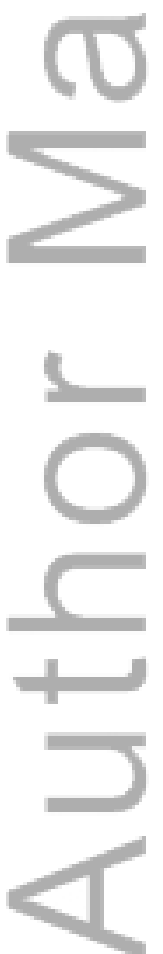

This article is protected by copyright. All rights reserved. 
Table 8- Functional Classification of Ankle Sprains

\begin{tabular}{|c|c|c|}
\hline Severity & Signs and Symptoms & Disability \\
\hline Grade 1 (mild) & $\begin{array}{l}\text { Minimal swelling (clear } \\
\text { definition of Achilles tendon; } \\
\text { small area of tenderness; } \\
\text { little/no haemorrhage; } \\
\text { minimal decreased ROM }\end{array}$ & $\begin{array}{l}\text { Minimal loss; little/no limp } \\
\text { with walking; difficult } \\
\text { hopping; expected recovery } \\
\text { 7-10 days with optimal } \\
\text { rehabilitation }\end{array}$ \\
\hline Grade 2 (moderate) & $\begin{array}{l}\text { Moderate swelling (margin } \\
\text { of Achilles tendon less } \\
\text { defined); more generalised } \\
\text { tenderness; some } \\
\text { haemorrhage; decreased } \\
\text { ROM }\end{array}$ & $\begin{array}{l}\text { Limping with walking or can } \\
\text { walk only a few steps; } \\
\text { unable to run; unable to hop; } \\
\text { unable to do toe raise; } \\
\text { expected recovery } 2-4 \\
\text { weeks with optimal } \\
\text { rehabilitation }\end{array}$ \\
\hline Grade 3 (severe) & $\begin{array}{l}\text { Diffuse swelling (no clear } \\
\text { margins of Achilles tendon); } \\
\text { diffuse swelling; } \\
\text { haemorrhage is evident; } \\
\text { pronounced decreased } \\
\text { ROM }\end{array}$ & $\begin{array}{l}\text { Unable to bear weight; } \\
\text { involuntary guarding with } \\
\text { exam; expected recovery 5- } \\
10 \text { weeks with optimal } \\
\text { rehabilitation }\end{array}$ \\
\hline
\end{tabular}

ROM- Range of Motion

This article is protected by copyright. All rights reserved. 

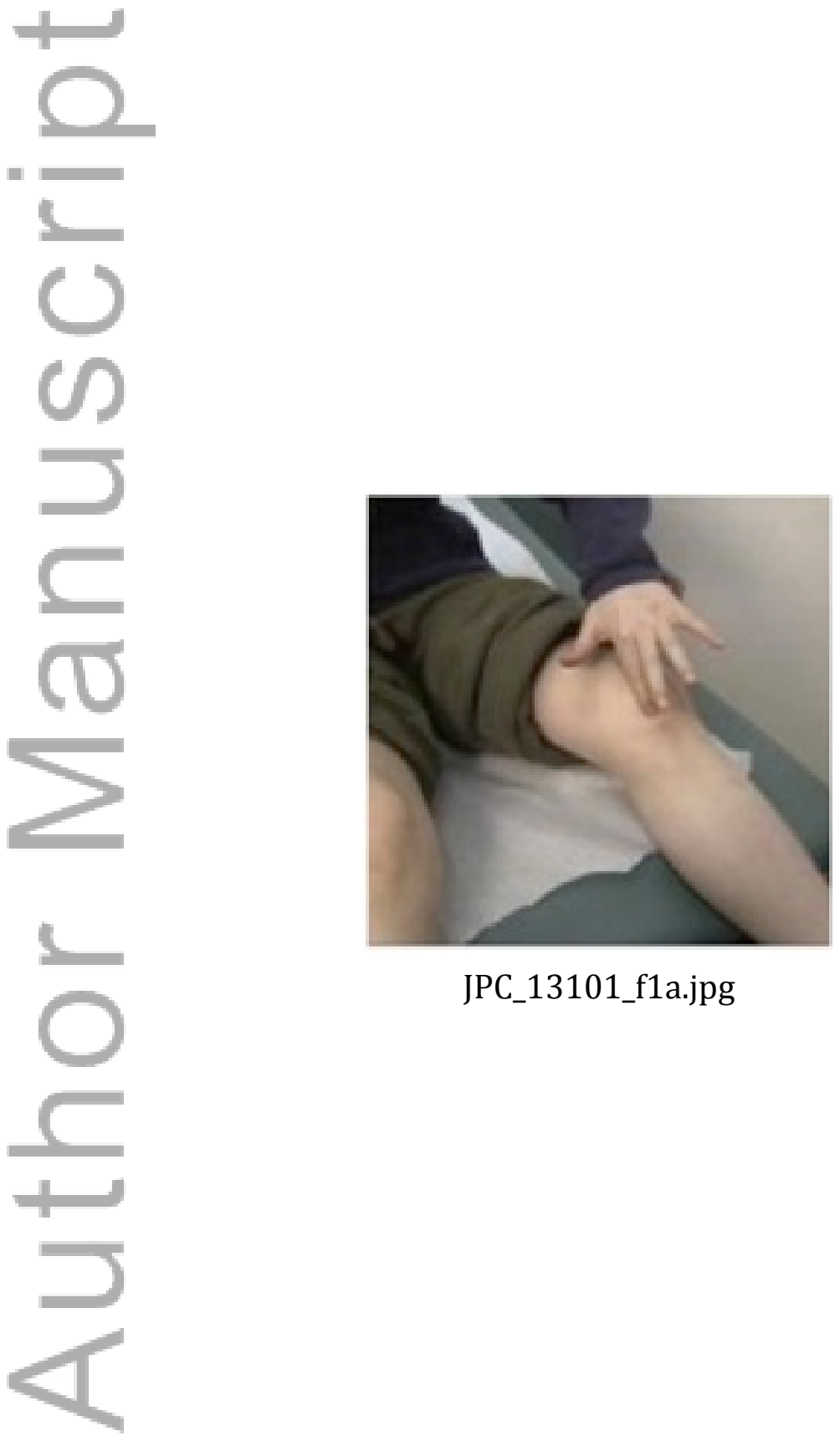

JPC_13101_f1a.jpg

This article is protected by copyright. All rights reserved. 

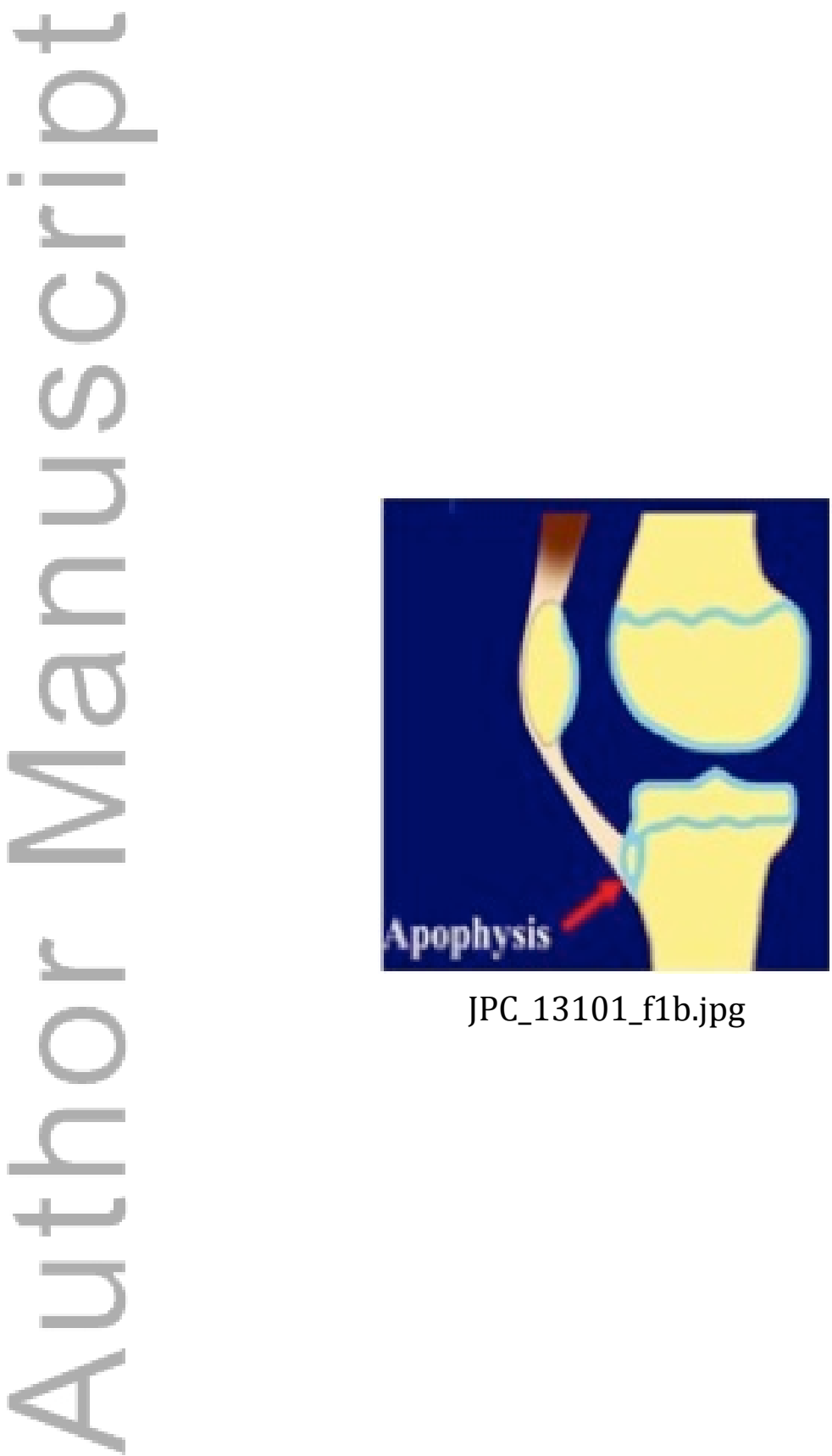

JPC_13101_f1b.jpg

This article is protected by copyright. All rights reserved. 

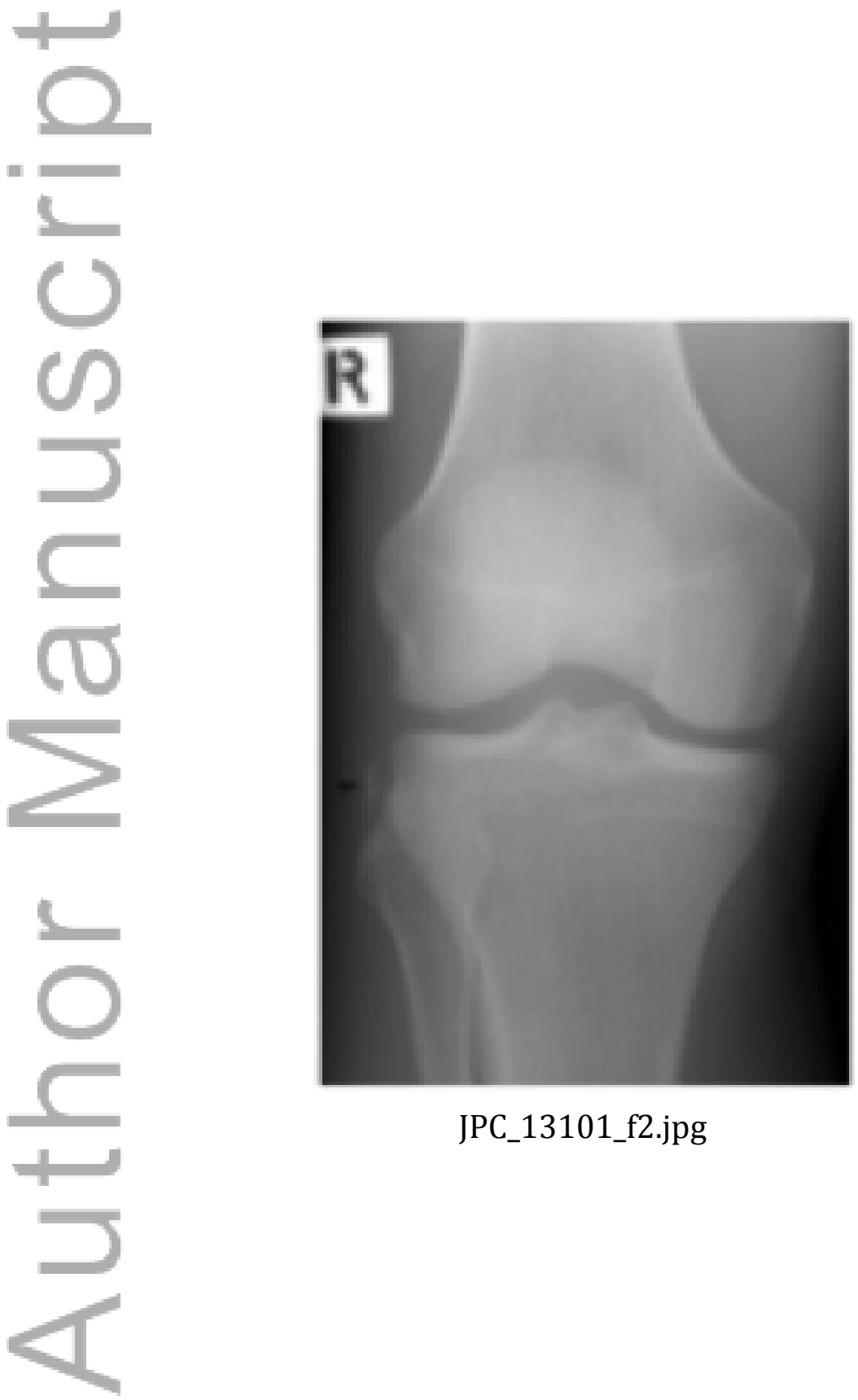

JPC_13101_f2.jpg

This article is protected by copyright. All rights reserved. 


\section{University Library}

\section{- M M N E R VA A gateway to Melbourne's research publications}

Minerva Access is the Institutional Repository of The University of Melbourne

Author/s:

Browne, GJ;Barnett, PLJ

Title:

Common sports-related musculoskeletal injuries presenting to the emergency department

Date:

2016-02-01

Citation:

Browne, G. J. \& Barnett, P. L. J. (2016). Common sports-related musculoskeletal injuries presenting to the emergency department. JOURNAL OF PAEDIATRICS AND CHILD HEALTH, 52 (2), pp.231-236. https://doi.org/10.1111/jpc.13101.

Persistent Link:

http://hdl.handle.net/11343/290880 